\title{
HUNTING TOURISM IN THE FUNCTION OF RURAL DEVELOPMENT OF HOMOLJE
}

\author{
Risto Prentović ${ }^{1}$, Branislav Živković ${ }^{2}$ Drago Cvijanovic ${ }^{3}$
}

\begin{abstract}
Summary
Homolje, an area in eastern Serbia, which coincides with the territorial area of the Municipality of Zagubica, is extremely rural. Despite the fact that it has significant natural resources, this area is among the least developed in Serbia. Decades of unfavorable economic situation in Homolje has led to permanent depopulation in the form of emigration to more developed centers in Serbia or abroad, on the one hand, and negative population growth, on the other hand. This pathogenic occurence can be prevented only by the appearance of economic recovery based on the concept of intensive rural development, i.e. operation of a set of interrelated economic activities and other activities (agriculture, manufacturing, forestry,water management, trade, tourism, crafts, hunting, fishing, etc.). Analysis shows that, according to available adequate resources, hunting tourism can become a significant factor in fostering rural development of Homolje. The subject of this research is dedicated to finding the place, role and potential of hunting tourism from the aspect of rural development of Homolje.
\end{abstract}

Key words: Serbia, Homolje, hunting tourism, rural development

JEL: $R 110, Q 15$

1 Risto Prentović Ph.D., Associate Professor University of Novi Sad, Faculty of Sciences, Department of Geography, Tourism and Hotel Management, Trg Dositeja Obradovića no. 3, 21000 Novi Sad, Serbia, E-mail: riprent@open.telekom.rs.

2 Branislav Živković, PhD, Tehnical school Žagubica, Homoljska bb, 12320 Žagubica, Serbia, E-mail: mrbane71@gmail.com

3 Drago Cvijanović, PhD, Full Professor, Faculty of Hotel Management and Tourism - Vrnjci Spa, University of Kragujevac, Serbia, Phone: + 38163295 111, E-mail: drago.cvijanovic@kg.ac.rs and dvcmmv@gmail.com

EP 2016 (63) 1 (71-87) 


\section{Introduction}

The most propulsive economic resources of the Republic of Serbia are located in the so-called rural areas. OECD defines a rural area as a place at the local level where the population density is up to 50 people per $\mathrm{km}^{2}$. According to the Council of Europe, a "rural area" is a stretch of land in the interior or on the coast, which includes smaller towns and villages, where the main part of the territory is used for: a) agriculture, forestry, water management and fishing, etc.; b) the economic and cultural activities of the population of the area (trade, industry, services); c) non-urban recreation and leisure activities; and d) for other purposes, such as housing (Lazić, 2007).

A rural area is, therefore, an area whose main physical and geographical feature is the use of the land primarily for agriculture and forestry. Rural areas include people, land and other natural resources in open areas and rural settlements beyond the immediate economic impact of major urban centers. Rural areas, as a rule, have fairly rich ecosystems and biodiversity is relatively preserved. When we add the number of physical and geographical, as well as climate conditions, it provides favorable conditions for the development of agriculture, forestry, water and their tangent activities.

On the basis of these resources, it is necessary, primarily at the local level, to integrate these and other activities in order to achieve synergies in the field of rural development in the rural areas.

Rural development can be defined as a function of a set of interrelated economic activities and other activities, which, in addition to primary agricultural production, include manufacturing, forestry, hunting, fishing, water management, trade, tourism, carfts, and a number of activities related to spatial planning.

Tourism has been a significant integrating factor of business and other ventures in rural areas in the last decades, and it has its specific form - hunting tourism, especially in areas with relatively preserved biodiversity (rich fauna and hunting).

One of the distinguished rural areas in Serbia is the area of Homolje. It is a small geographical area in Eastern Serbia, which is located between $44^{\circ} 05^{\prime}$ and $44^{\circ} 22^{\prime}$ of north latitude and between $21^{\circ} 31^{\prime}$ ' and 21 ${ }^{\circ} 50^{\prime}$ of east longitude (Miljković, 1992). Administrative area of Homolje entirely belongs to the municipality of Zagubica. The subject of this research is finding the place, role and potential of hunting tourism from the aspect of rural development of Homolje. 
Map 1. Municipality Žagubica

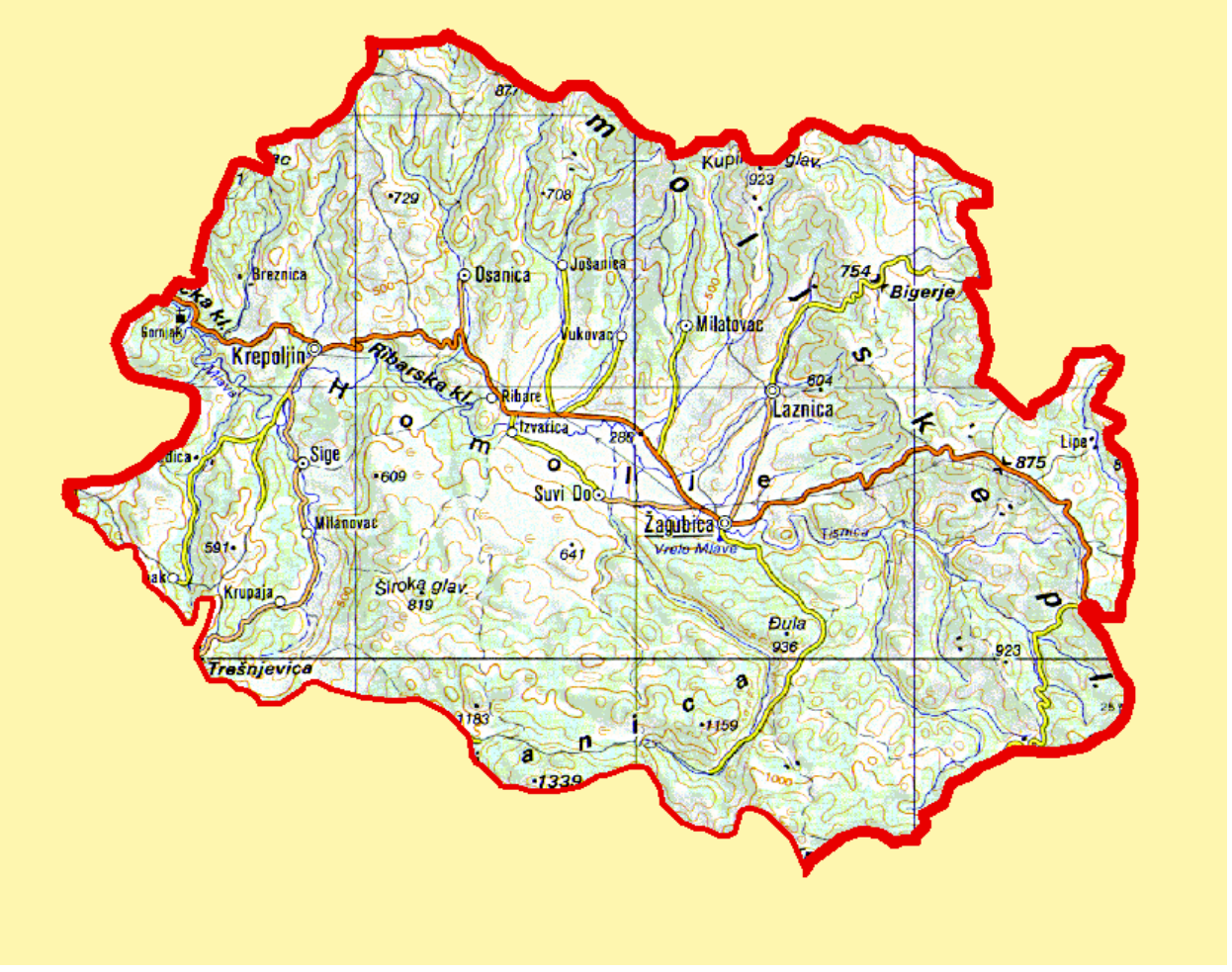

Source: Various authors (2009.), „Strategija održivog razvoja opštine Žagubica 2009 -2013“, Žagubica.

\section{Material and methods}

Empirical data are the written materials (scientific and technical literature, laws and regulations, planning documents and other relevant documents of business entities and local communities of Homolje) and factography (and recordings of observations and tests) from the field. For processing, analysis and discussion of the research results, the following scientific methods were used:

- Systematic observation,

- Analysis (of the literature and factual) content,

- Interviews with competent people in the field, and

- Statistical methods (descriptive statistics). 


\section{The position and size of Homolje}

The area of Homolje has an irregular rectangle shape positioned in the direction of east-south-east - west - north-west, with a length of about $35 \mathrm{~km}$, while the widest point is about $26 \mathrm{~km}$ (Živković, 2011). Its territory is surrounded by mountain ranges on all sides. It is separated by Homoljske mountains $(940 \mathrm{~m})$ from Zvižd on the north, by the mountain crown of Beljanica (1336m) from Resava on the south, by the Crni Vrh massive (1027m) from the Crna Reka basin in the east, and by Gornjak low mountains $(825 \mathrm{~m})$ from the lower plains of Mlava in the west. Geomorphological unit of Homolje consists of two parts: Žagubička valley to the east and Krepoljinsko-Krupajska valley to the west, between which there is Beljaničko-Homoljska rung (Miljković, 1992).

Size of the territory Homolje, generally the Municipality of Zagubica, is $759.99 \mathrm{~km}^{2}$, and there are 16 villages, of which the largest are Žagubica and Krepoljin. Neither of these settlements is of the predominant urban character.

As for the constructed transport infrastructure, Homolje lags behind the national average. It is located about $170 \mathrm{~km}$ away from Belgrade, and the main traffic corridor is the regional road R 105 Pozarevac - Petrovac - Žagubica - Bor. Two more regional roads pass through the territory of Homolje, as follows: R 104 Žagubica - Majdanpek and R 216 Krepoljin - Despotovac, which are of much lower quality than the aforementioned road R 105. All the villages in the municipality of Žagubica are connected via the local road network. The main roads in the area of Homolje are only $14 \mathrm{~km}$ long with the length of the local road network of $102 \mathrm{~km}$.

\section{Flora and fauna}

Geological and pedological, climatic and hydrological features in a given geographical area, along with anthropogenic influences, constitute distinctive geographical characteristics of the Homolje area.

Floristic composition of Homolje is heterogeneous, and in that territory the regions that are characterized by specific plant associations can not be clearly distinguished nor delineated. Some differences in the horizontal extent of individual plant species are the result of local differences in the composition of soil, underground water depth, slope, sunlight and others. There is no clear zone division in the presence of individual plant units, although grass and forest cover, including associations that can be divided into separate units, can be distinguished as separate units (Miljković, 1992).

Grass phytocoenoses is spread without zones, i.e. from the lowest valley level to the highest mountain ranges, consisting of associations of marsh vegetation and the representative lush valley meadows and mountain pastures. Forest vegetation of Homolje is represented by several types, depending on the quality and type of soil, as well as the altitude. In the valley of Mlava and its tributaries, there is willow, poplar and elm. In the medium altitude there is oak, maple, hornbeam, hawthorn and other trees, and above this zone there are beech forests, as the most common in Homolje. Coniferous forests cover small areas and are represented in fragments, located in areas 
deforested by unplanned cutting, where the erosion was intensive (Miljković, 1992).

Theterritory of Homolje is inhabited by diverse wildlife, and due to a significant refinement of the territory, the wildlife has been pushed back to the forest and grass fields of the surrounding mountains, which made the habitats of many species very limited. Hunting game in the territory of present Homolja includes deer, wild boar, rabbit, pheasant and partridge, as well as predators (wolves and foxes, and more recently jackals). In almost all rivers of Homolje, especially in mountain streams, ichthyofauna (trout, barbel, chub, gudgeon and carp) is significantly represented.

\section{Population of Homolje}

According to census from 2011, there are five citizens per square kilometer in Homolje, making this area one with the smallest population in Serbia. Depopulation is a constant feature of the demographic picture of the area in the last half of the century, as evidenced by all population censuses since 1961 (Živković, 2011). The age structure of the population is quite unfavorable because more than a quarter of the population $(25.7 \%)$ is older than 65 years of age. Working population share in Homolje is $56.8 \%$. Of the total population aged over 15 years, even $12.2 \%$ have no educational qualifications, and $33.9 \%$ have not completed primary school. On the other hand, only $2.6 \%$ of the given population hold a university degree. Ethnically there is the largest number of Serbs, while Vlachs are also present as a national minority.

\section{Economy of Homolje}

Homolje is one of the least developed areas in the Republic of Serbia. According to official statistics, its share in the gross domestic product of the Republic of Serbia is only $0.06 \%$ (Republic Statistical Office, 2007). Domestic product per capita in the municipality of Žagubica is $50,081.00$ RSD, which is less than $40 \%$ of the national average. Agriculture has the major role in the economy of Žagubica, that in the total new value has the share of $56.33 \%$, which clearly speaks of its dominance. Far behind, there is the manufacturing industry with $10.23 \%$ and trade with $7.93 \%$ Motels, restaurants, bars, and cafe bars account for $2.84 \%$. According to the same source, in the municipality of Žagubica in the treated period (and by all indications, the situation has not significantly changed even today), there were a total of 1,476 people employed, while the number of unemployed was 763 people. At 1,000 people, 131 were employed and 24 were unemployed. Although the number of employees should be treated with caution, the data show that the number of employees is more than twice lower than the national average, because in that period, of the average of 1,000 people 271 people were employed. 
Table 1. The share of economic activity in the formation of domestic product of Žagubica unicipality

\begin{tabular}{|l|l|}
\hline Activity & 2010. \\
\hline Agriculture, hunting, forrestry and wate management & $59.33 \%$ \\
\hline Fishing & $0.49 \%$ \\
\hline Mining ore and stone & $8.23 \%$ \\
\hline Processing industry & $8.26 \%$ \\
\hline Production of electricity, gas, and water & $2.13 \%$ \\
\hline Construction industry & $4.80 \%$ \\
\hline Wholesale and retail trade, repairs & $6.93 \%$ \\
\hline Hotels and restaurants & $2.84 \%$ \\
\hline Transport, storage and communications & $5.61 \%$ \\
\hline Real estate and rental business & $0.25 \%$ \\
\hline Healthcare and social work & $1.1 \%$ \\
\hline Other communal, social and personal services & $0.00 \%$ \\
\hline Total & $100.00 \%$ \\
\hline
\end{tabular}

Source: Republički zavod za statistiku, 2012.

Due to the severe economic underdevelopment and the lack of production and processing capacity, a large number of people migrated from the area to the big cities or to the EU. The economy is still underdeveloped in Žagubica and tourism could be the engine of development with regards to the potential that the municipality has. The problems young people who stayed in the area are facing are very strong, and they necessitate finding the solution. According to the above presented resources in Homolje area, one of the relevant solutions to this problem, therefore, is to intensify the development of tourism and its related activities.

Tourism potential of Homolje could be defined by several parameters:

- Tourist position of the municipality of Žagubica represents the relation to the routes of tourist developments, both domestic and foreign. The road transport has the largest importance given level of the construction of infrastructure. The quality and density of the road infrastructure is very poor.

- Natural tourist values. The municipality of Žagubica is characterized by a wealth of natural features such as: mountain ranges that surround it (Beljanica, Homoljske Mountains, Gornjak Mountain, Crni vrh); gorges and canyons (Gornjačka Gorge); a large number of springs (Mlava spring, Krupajsko spring); thermal sources (spas); natural stone bridges (rare forms of karst terrain - Osanički natural stone bridge), sinkholes, multi-coned closed depressions, hydrographic values (Mlava river, numerous springs and wells); biogeographical value (forest expanses, hunting, fishing areas).

- Historical tourist values are reflected in the archaeological sites from the Roman period that were used to secure the important Roman road "Via Militaris" which went through the Gorges of Mlava; monuments of medieval culture (remnants of the 
medieval walled city of Pharynx, Blagoveštanje monastery, the monastery Gornjak, Trška Church) .

- Ethnographic tourism value of the area associated with the Serbian and Vlach population. It is reflected in the abundance of customs, folklore, costumes, culinary specialties.

- Events as tourist attractions: "Golden Hands of Homolje”, reconstructed "Homoljski motives" (Springs of Homolje) in Žagubica (which always takes place in the days of the Holy Trinity in the period (May-June); Spasovdanski meetings in Krepoljin; chase for Homolje wolf in Žagubica, (held every year in mid-January) and "Days of fungi and plants" in Krepoljin (held every year in September).

Accomodation tourist facilities in Homolje are insufficient for accomodation of a large number of tourists, especially in the time of the events, because in the entire Homolje region there is only one motel, "Vrelo", with a capacity of 80 beds where tourists can get lodging. The restaurant capacity is 400 seats. Six other restaurants operate on the territory of Homolje with capacities ranging from 30 to 100 seats for dining. With the appropriate rehabilitation and reconstruction, abandoned farms and bachia that have an unused potential, can be adapted for the needs of lovers of nature, fishing, and hunting (Živković, 2011). The general opinion of the competent experts is that these natural resources should be animated, integrated and economically effectuated into a complex form of tourism, which is rural tourism. Generally, it covers all tourism activities in rural areas. According to one definition. it is "a wide range of activities, services, and delights 'secured' by the farmers in order to attract tourists to their area in order to create additional income." (Hall, Kirkpatrik and Mitchell, 2005).

The Council of Europe (in 1986) defined the rural tourism as an activity that includes all activities in the rural area, and its main features are calm and preserved environment, the absence of noise, communication with local people, local food and familiarization with rural activities (According to: Todorović, Štetić, 2009). This is a broader definition, and the narrow one is: "a wide range of activities, services, and delights provided by farmers and peasants in order to attract tourists to their area for creating additional income." (Lazić, 2007). Rural tourism is, therefore, tourism in rural areas, and it can incorporate almost all the activities carried out there. Natural resources in rural areas enable the introduction of new non-agricultural activities (including rural tourism), which ensures the creation of additional revenue. This, in turn, improves the quality of life and stop the demographic decline in these areas. Consequently, income from rural tourism can support the economic and general recovery of rural areas. Moreover, rural tourism is a suitable tool for the revitalization of abandoned rural areas by increasing the diversity of occupations and job creation, as well as the conservation and improvement of the environment, which is the basis for their prosperity in the future. Therefore, it serves to stimulate economy growth, to increase the opportunities of underdeveloped areas, and to improve the standard of living of the local population. 
Analyzing a number of literature sources that deal with this issue, it can be concluded that rural tourism is characterized by the following (Todorović, Štetić, 2009)

- It is located in rural areas

- Represents and promotes open space,

- Intimate contact with nature and the natural world, and is an integral part of it,

- Respects the heritage of "traditional" societies and practice,

- Allows participation in all activities, traditions and way of life of local population,

- Provides personalized contact,

- Provides a high percentage of revenue from tourism and benefits the rural community.

Rural tourism is often considered to be a form of tourism which has sustainability, i.e. it attracts few visitors, it does not require major infrastructure development, and tourists are usually genuinely interested in the local culture and tradition. However, opinions are divided on the economic viability, i.e. profitability of rural tourism, as the demand is mostly seasonal, occupancy is low, and investments in tourism infrastructure and superstructure are often high.

Some researches of the issues of rural tourism in Serbia indicate that this form of tourism can be profitable provided that integration and connection with other forms of tourism in rural areas, such as, among others: ecotourism, ethno-tourism, spa tourism, recreational tourism, fishing and especially hunting tourism, is achieved.

\section{Potentials of hunting tourism in function of Homolje's rural development}

Hunting tourism is an activity that, on the one hand, belongs to hunting as a form of economic activity, and on the other, it is a special form of tourism. The main purpose and outcome of hunting is, in fact, the activity that brings significant economic benefits. For example, according to information obtained by Kurjački (2011), only in the United States, during 2006, 12.5 million hunting participants made a turnover of over 25 billion dollars. The same author has come to the conclusion that, for example, in Tanzania, trophy hunting within the hunting tourism activities, has brought the average financial gain of up to 40 million dollars a year at the beginning of this century, with the tendency of continual growth and, as such, has a very important role in rural development of the country (Milojević, Pejić, 2010).

One author (Vujović, 2011) places an emphasis on the economic function of hunting, whose purpose is, primarily, the protection and improvement of the habitat conditions for the existence of the game, their care, protection, and sustainable exploitation, and secondly, the reduction of damage caused by wild animals by reducing their overpopulation in biotopes (Marić, 2003). In this context, hunting is defined as "a set 
of human activities that are aimed at harmonizing the relationship between man and animals, based on the knowledge of the basic biological characteristics of the individual species, environmental factors (conditions) of space, and most important tenets and principles of integrated management, rational use and sustainable development."

In defining hunting, other authors favored its economic dimension by defining it as an "economic activity, which cannot be precisely determined and belonging to production or service industry. It includes both of the aforementioned notions, because it involves cultivation, preservation and use of shot game which could be considered belonging to production industry and defined by the concept of hunting management. Equally, it includes hunting tourism as the most profitable branch of hunting economy, which could be considered as a service industry."(Šelmić et al., 2001).

A more comprehensive and a more extensive explication defines hunting "as a complex human activity, that is, the activity of special social interest and importance in the function of rational and sustainable hunting, permeated with the spirit of humane, chivalrous, and permissive attitude towards the game and nature in general; an activity for whose purpose the additional activities of the hunting industry are conducted: care, protection, and the use of game and hunting areas, scientific research and protection, and the enhancement of natural habitats and the environment of hunting game" (Prentović, 2006).

The importance of hunting is also reflected in its contribution to the development of other industries including: agriculture and forestry (by encouraging the cultivation of the cultures used for the nutrition of the game, forestation, planting trees and shrubbery, protection of forest seed-stands and agricultural crops from wild animals, etc.), tourism (through tourist-hunting activity), catering industry (by expanding the network of restaurants and the use of game meat in their cuisine), commerce (by selling items of meat, skin, fur, antlers, tusks, bones of wild animals, etc.), and also other industries, such as travel and telecommunications industry, and others (i.e. those that produce hunting weapons, ammunition, equipment, clothing, souvenirs, etc.).

Rural areas, such as Homolje, as it has been argued, have rich ecosystems and biodiversity, and from that aspect, hunting may represent a significant contribution to rural development, both in economic, and social and environmental aspects. The necessity of agriculture diversification in rural areas necessitates the introduction of various economic activities to the agricultural households, which in that way, have an opportunity of claiming the additional revenue. Tourism industry, or hunting tourism as its selective form, may represent the quickest and most economical way of rural development.

Professional literature has given a few relevant definitions of hunting tourism. It seems that the most acceptable is the one which assumes this form of industry as "the movements and active stays of tourist-hunters in specific surroundings - a hunting ground, as a part of a healthy natural environment - in order to hunt (shoot, capture, observe and record) game, by which, its participants (hunters-tourists) satisfy a strong motive (a primary hobby, and a passion to some). At the same time, these participants pay the fee for the shot game (trophies, meat, leather, etc.), accommodation, and food 
in adequate catering facilities, as well as other contractual services, according to price lists valid at the time" (Prentović, 2008).

The specific characteristics of hunting tourism are:

- It occurs mostly outside the tourist attractive areas, and outside the main tourist season

- The income from tourism in highly significant for organizations which deal with the conservation, cultivation and use of wildlife;

- The range of general tourist offers of Serbia is complemented and enriched by huntingtourist offer (Prentović, 2005).

Mediation in hunting tourism, organization and execution of the hunt, renting vehicles for the transport and accommodation of tourist-hunters, hunted wild game processing, evaluation big game trophies, rental of hunting weapons, providing hunting ammunition, and other services for hunters-tourists during hunting, are considered as services in hunting tourism.

In relation to other forms of tourism, the specificity of demand in the hunting tourism lies in its multiple layers, which is based on the specific needs of tourist-hunters, and those needs, besides hunting, are: active leisure and recreation, staying in healthy natural environment, enjoying natural beauties, or the exotic landscapes of hunting grounds with specific biocenoses and attractive species of flora and fauna, educating for successful hunting tourism activity, etc. On the other hand, in addition to the diverse and prime trophy game, hunting-tourism product assumes other types of services, primarily: accommodation, meals, transportation, educational, cultural, fun, and recreational services and activities and the like.

As a segment of hunting, hunting tourism is closely associated with a greater number of economic and non-economic activities, especially with forestry, agriculture, water management, sports, education, science, culture and others. This is so because the hunting in the formation of their "product" depends on the resources of these fields. Thus, for example, forestry, agriculture and water management provide hunting, that is, hunting tourism, the necessary spatial and environmental milieus for the existence of game, as the main motivation for hunting-tourist recreational activities. These industries also provide the grounds for the implementation of hunting tourism as the main segment of hunting tourism offer. The enlisted economic activities provide the elements for enriching hunting-tourist offers with programs which include sport, educational, cultural (including festivals) and scientific-specific character. Hunting tourism reciprocates these (economic and non-economic) activities by allowing them to participate in the distribution of income generated through hunting-tourist turnover.

Hunting tourism, a future section (a segment, a selective form) of tourism, correlates with industries, such as catering, transport, trade, and other trades. This is because accommodation services, food and transport of tourist-hunters, their supply with various necessary items (hunting weapons, ammunition, equipment), souvenirs and provision of certain services (repair of weapons, equipment, etc.) represent a significant part of the structure of hunting-tourist product. 
Research conducted shows a high correlation of hunting with rural tourism. It consists in the fact that hunting areas (hunting grounds) are fully located in rural areas; therefore, catering facilities of both hunting and rural tourism may offer its services to the clientele of both of these branches of tourism. The connection of these two forms of tourism is also reflected in the field of tourist demand in such a way that a statistically significant number of hunter-tourists prefer to spend their stay in hunting-tourist destinations with other people (family members, business partners, a business escort) who might not be fans of hunting, and prefer exploring new and unfamiliar landscapes and gaining new experiences and knowledge.

As an integral and most propulsive economic segment of hunting, hunting tourism gets a significant part of the income returned, which is mainly directed to the production, care and protection of wildlife, i.e. bringing the same number of specific units of game which had been brought out of the hunting grounds. In addition, a part of the financial resources obtained through hunting tourism focuses on investing in order to improve the overall conditions for the implementation of the hunting tourism and hunting in general (construction and maintenance of the facilities for: hunting tourism, food and accommodation of tourists, various other services for tourists in hunting, such as transportation equipment, etc.). Therefore, the notion that hunting tourism is the main generator of the development of hunting is based on strong grounds.

There is one functional hunting ground on the territory of Homolje whose name is identical to the name of the area. It is now a respectable hunting tourism destination in Serbia. Hunting ground "Homolje" is managed by the Hunting Association of Serbia through the Hunting Association "Jovan Šerbanović" from Žagubica. It was found by the decision of the Ministry of Agriculture, Forestry and Water Management No. 32402-00095/4-05-10, published in the "Official Gazette of the Republic of Serbia" No. 70/2005. from 29.06.2005. Hunting ground "Homolje" covers the areas of forests, land, and water territory Žagubica, an area of 71,791 ha. Hunting areas (all parts of the hunting grounds where game has all the necessary conditions for survival and reproduction, and on which it is bred, protected and used, i.e. hunted) encompass 67,200 ha or $93.61 \%$ of the total hunting ground "Homolje." Structure of hunting "Homolje" is shown in Table 2.

Table 2. Structure of hunting grounds "Homolje"

\begin{tabular}{|l|l|l|}
\hline Forrest and forrest grounds & $32,988.00$ ha & $45.95 \%$ \\
\hline Meadows and pastures & $25,122.00$ ha & $34.99 \%$ \\
\hline Arable lands and gardens & $9,090.00$ ha & $12.67 \%$ \\
\hline Orchards and vineyards & $2,715.00$ ha & $3.78 \%$ \\
\hline Other & $1,876.00$ ha & $2.61 \%$ \\
\hline
\end{tabular}

Source: Popović, 2005,

Due to the favorable natural and geographical conditions, hunting ground "Homolje" represents a habitat or a stopping-off point for many species of game. The species of game that are bred in it are: roe deer, wild boar, rabbit, pheasant and partridge, and the migratory birds that are also present (during migration and nesting) include: quail, 
woodcock, wood pigeon, dove, wild goose, wild duck and others.

Table 3. Productive hunting area of hunting ground "Homolje" designated for breeding game

\begin{tabular}{|l|l|}
\hline Type of game & $\begin{array}{l}\text { Productive hunting } \\
\text { area in hectares }\end{array}$ \\
\hline Roe deer & 45.000 \\
\hline Wild boar & 33.000 \\
\hline Rabbit & 45.000 \\
\hline Phaesant & 15.000 \\
\hline Partridge & 20.000 \\
\hline
\end{tabular}

Source: Popović, 2005.

Table 4. The number of bred game in hunting ground "Homolje" on the day 01.04.2013.

\begin{tabular}{|l|l|}
\hline Type of game & Numbers (cirka) \\
\hline Roe deer & 1120 \\
\hline Wild boar & 230 \\
\hline Rabbit & 3200 \\
\hline Phaesant & 2605 \\
\hline Partridge & 1750 \\
\hline
\end{tabular}

Source: Internal documents of the Hunting Association „,Jovan Šerbanović“, Žagubica

Over the last few years, migratory movements of deer game and chamois from neighboring hunting grounds to hunting ground "Homolje" have been registered. For now, hunting ground "Homolje" does not manage deer and chamois, but the project for the reintroduction of deer from other hunting grounds to hunting ground "Homolje" is being developed.

Predatory species of furred game that are present and allowed to be hunted are: foxes, martens, wild cats and wolves. When it comes to the jackal, in the last eight years three shootings have been registered, one of which was killed under the wheels of a car. A special feature is the occurrence of lynx on Beljanica, whose presence has been determined in this location. The number of foxes varies from year to year, and the number of this population is largly influenced by infectious diseases that decimate this species. On the other hand, apparent increase of lynx and wild cats has been evidenced. The wolf population can be characterized as stable with a slight increase in number. The foregoing data points to the existence of attractive hunting species in the hunting ground "Homolje."

Throughout the twentieth century Homolje, as a hunting, or a potential hunting-tourist destination, remained unknown to a large number of people who love nature and hunting in this country (Yugoslavia and Serbia), let alone abroad. Not before 2002 does the active promotion of hunting-tourist potentials of this destination begin. In the last ten years, large hunting-tourist events included three wolf-chases, which have 
shown that there is a huge positive impression on the hunting public for hunting in Homolje. Besides the local hunters chases have been attended by hunters from abroad: Austria, Germany, Czech Republic, Slovenia, France, Italy, and representatives of the diplomatic corps accredited in the Republic of Serbia.

Experience shows that such events have been useful, not only for the aforementioned hunting association, but also for traders, caterers, bakeries, transportation companies from the territory of Homolje and beyond. This is because these events were attended by hundreds of hunters. Acceptance of such a large number of guests and quality arrangement of the hunt, represented a highly complex and delicate task of securing the area, because it required coordinated efforts of many economic and other subjects for serving hundreds of clients in short and limited time frames. At the same time, the lack of catering facilities on the territory of Homolje represents the crucial limitation which determines the stay of the majority of guests in this area to less than 24 hours limit. As a result, the financial effect of these events was much lower than would have been, if the events had lasted for more than one day.

The current activity of the hunting ground "Homolje" is organizing individual and group (up to 30 participants) tourist hunts. Past experience has shown that the organization of such hunts for hunters-tourists is in many ways simpler than the hunting-tourist events such as wolf-hunts. Hunter-tourists have expressed a great interest in hunting wild boar from a hunting stand, and with bay and catch dogs, which is very attractive in Homolje, primarily due to the abundance of game and terrain configuration.

Besides the wild boar offer, hunting grounds "Homolje" offers roe deer hunt to huntertourists, which is a special attraction due to the beautiful landscapes of roe deer habitat. Although a mountainous region, it is particularly interesting that Homolje is rich in feathery game. Foreign hunters have expressed particular interest in hunting pheasant, woodcock and partridge. Following the latest trends that dominate the market, the Hunting Association "Jovan Šerbanović" prepares a special offer to the interested clientele in the form of increasingly attractive and interesting form of hunting tourism - a photo-safari.

Development of hunting tourism in Homolje in the past few years has been marked by a close relationship between the local self-government, tourism organizations and hunting associations. Building awareness that hunting is a part of the cultural heritage of the population of Homolje, and that Homolje is one of the most attractive hunting areas in the country, has encouraged both the local government and the tourist organization to provide means to the hunters' association, in promoting hunting tourism potentials of Homolje at fairs and other events for the promotion of tourism. Real income opportunities and job openings have caused the inclusion of such entities in the idea of developing hunting tourism and actualizing these ideas on the field (Živković, 2011). 


\section{Conclusion}

As displayed by the presented facts, Homolje belongs to one of the most economically underdeveloped areas in Serbia, being an extremely rural area. On the other hand, it has significant natural resources at its disposal. In the last half of the century, as a result of economic underdevelopment and lack of prospect, there has been a constant decline in the population of Homolje, one of the reasons for which has been negative population growth, the other being the migration of working-age population to the developed centers (Belgrade, Nis, etc.), and abroad to a large extent.

A favorable opportunity for economic development and ending depopulation trends of Homolje lies in intensifying its rural development by activating existing natural and human resources, with adequate integration of promising industries and sectors (agriculture, forestry, mining, energy, tourism, hunting, fishing). That requires substantial endeavors to improve the necessary conditions for the development of the aforementioned industries and activities. The assessment of the acclaimed scientists and surveyed experts is that hunting tourism - among other industries or activities could be one of the important factors of rural development of Homolje, but in order to be so it is necessary to accomplish the following prospects:

-To significantly improve transportation infrastructure of the area and a wider region (Braničevo District) by building a quality road network, especially the roads that connect this region with Corridor X (road and railway line Belgrade - Nis - Bulgaria), and connect Bor and Timočka Krajina with Bulgaria and Romania. It is also necessary to establish an extensive road network through all the areas of the hunting grounds which would be suitable for the movement of off-road vehicles, so as to comfortably transport hunter-tourists to their hunting preserves, that is, to enable hunting game from vehicles to those who prefer it (of course, when a vehicle is not in motion).

- With the support of the wider community, particularly from the potential investors, and by the reparation and reconstruction of the existing catering facilities, the Local government, Tourist Organization of Žagubica Municipality and the user of hunting ground "Homolje" should enable the construction of additional high-quality accommodation facilities for hunting-tourist and tourist offers in general, by organizing events that gather a large numbers of tourists, such as hunters assemblies on an international level, as well as other events in the field of ethnic, ecological, cultural, rural, fishing, sports and recreation tourism (e.g. rafting) and others.

- Professionalization of the general management of hunting ground "Homolje" so as to ensure that highly professional and interdisciplinary funded realization of complex activities of breeding, securing, and sustainable use of game, as well as efficient management and marketing of hunting-tourist activities of this hunting destination. Favorable opportunities for this are provided by certain regulations of the new tourism laws on both game and hunting, and it is up to hunting and tourism workers of Homolje to implement these laws in their practice as soon as possible, so that the basis of hunting tourism personnel in this area could produce and successfully market a high-quality 
and competitive hunting-tourist product.

- Since hunting-tourist activity can not successfully exist or function by itself if it does not have a firm stand in the entirety of the economy and other industries - especially if it is absent from the tourist offer of one area - there is a necessity for a stronger connection and integration of all the relevant subjects of this destination when it comes to designing, planning, operationalization and placement of a complete tourist product, the part of which being a hunting-tourist product, that would make the fundamental correlative link and the backbone which constitutes a recognizable brand of this area.

By implementing these prospects, the hunting-tourist destination of Homolje would constitute a very respectable potential of Serbian hunting-tourist offer, the basis of which is the presence of the varieties of game for hunting, and attractive hunting preserves of hunting ground "Homolje", which is why it is considered exceptional, distinctive and different from the others. All this can ensure that hunting tourism in Homolje becomes one of the important factors of rural development of this region, which will, ultimately, enable realization of more significant income, thus opening new jobs and hiring people.

\section{Literature}

1. Vujović, S. (2011): Turizam i ruralni razvoj-savremene tendencije, problemi i mogućnosti razvoja, Tematski zbornik, Trebinje, ISBN-978-99955-664-0-1. COBISS.BH-ID 1373720, Republic of Srpska CIP: 338.48(082).

2. Hall, D. Kirkpatrick, I., Mitchel, M. (2005): Rural Tourism and sustainable Business, Cromwell Press, Great Britain. pp. 371.

3. Kurjački, A. (2011): Lovstvo u funkciji ruralnog razvoja Bačke, Megatrend univerzitet, Beograd, Fakultet za biofarming, Bačka Topola (master thesis), Bačka Topola, p. 103.

4. Lazić, L. (2007): Ruralni turizam, Prirodno-matematički fakultet Novi Sad, Departman za geografiju, turizam i hotelijerstvo, p. 275.

5. Marić, R. (2003): Lovstvo, Institut ekonomskih nauka, Beograd, p. 169.

6. Milojević, I., Pejić, D. (2010): Knjigovodstvo i njegov razvojni put, Oditor, No. 1, pp. 10-16.

7. Miljković, Lj. (1992): Homolje (geographic scientific monograph), Prirodnomatematički fakultet, Institut za geografiju, Novi Sad, p. 197.

8. Miljković, Lj. Marković, S. (1985): Turistička valorizacija prirodnih potencijala Homolja, Zbornik radova Instituta za geografiju Prirodno-matematičkog fakulteta, Novi Sad, Vol. 15, pp. 133-154.

9. Popović, Z. (2005): Lovna osnova lovišta „Homolje“ 2005-2015. Lovačko udruženje „Jovan Šerbanović“, Žagubica,

10. Prentović, R. (2005a): Lovni turizam, Prirodno-matematički fakultet, Departman za geografiju, turizam i hotelijerstvo, Novi Sad, p. 204.

11. Prentović, R. (2005b): Lovnoturistički proizvod, Turizam, Vol. 9, pp. 161-163.

12. Prentović, R. (2006a): Osnovi lovstva, Prirodno-matematički fakultet, Departman 
za geografiju, turizam i hotelijerstvo, Novi Sad, p. 259.

13. Prentović, R. (2005b): Lovište - svojevrsna turistička destinacija, Turizam, Vol. 10, pp. 203-205.

14. Prentović, R. (2008a): Etika lovnog turizma, Prirodno-matematički fakultet, Departman za geografiju, turizam i hotelijerstvo, Novi Sad, p. 198.

15. Prentović, R. (2008b): Korelacija lovnog i ruralnog turizma u Vojvodini, Zbornik radova Departmana za geografiju, turizam i hotelijerstvo, Novi Sad, Vol. 37, pp. 110-121.

16. Republički zavod za statitistiku, 2007. Opštine Srbije 2006., Beograd

17. Šelmić, V., Gačić, D., Ćeranić, A. (2001): Lov i lovna privreda, Jugoslovenski pregled, 3: p. 130-132.

18. Todorović, M. Štetić, S. (2009): Ruralni turizam, Univerzitet u Beogradu, Geografski fakultet, Beograd, p. 160.

19. Živković, B. (2011): Formulisanje modela održivog razvoja turizma Opštine Žagubica, Megatrend univerzitet Beograd, Fakultet za menadžment Zaječar (doctoral thesis), Zaječar, p. 208. 


\title{
LOVNI TURIZAM U FUNKCIJI RURALNOG RAZVOJA HOMOLJA
}

\author{
Risto Prentović, ${ }^{4}$ Branislav Živković ${ }^{5}$, Drago Cvijanović ${ }^{6}$ \\ Rezime
}

Homolje, oblast u Istočnoj Srbiji, koja se teritorijalno poklapa sa područjem Opštine Žagubica, izrazito je ruralno područje. I pored toga što raspolaže značajnim prirodnim resursima ova oblast spada među najnerazvijenije u Republici Srbiji. Višsedecenijska nepovoljna ekonomska situacija u Homolju dovela je do permanentne depopulacije $u$ vidu iseljavanja u razvijenije centre u Srbiji ili u inostranstvo, s jedne, i negativnog prirodnog priraštaja stanovništva, s druge strane. Ovu patogenu pojavu može sprečiti jedino ekonomski oporavak zasnovan na konceptu intenzivnog ruralnog razvoja, tj. funkcionisanja skupa međusobno povezanih privrednih delatnosti i drugih aktivnosti (poljoprivrede, prerađivačke industrije, šumarstva, vodoprivrede, trgovine, turizma, zanatstva, lovstva, ribarstva i dr.). Analize pokazuju da, shodno raspoloživim adekvatnim resursima, lovni turizam može postati značajan faktor pospešivanja ruralnog razvoja Homolja. Predmet ovog istraživanja upravo je posvećen sagledavanju mesta, uloge $i$ potencijala lovnog turizma na planu ruralnog razvoja Homolja.

Ključne reči: Srbija, Homolje, lovni turizam, ruralni razvoj

4 Vanredni profesor, dr Risto Prentović, Univerzitet u Novom Sadu, Prirodno-matematički fakultet, Departman za geografiju, turizam i hotelijerstvo, Trg Dositeja Obradovića br. 3, 21000 Novi Sad, Srbija, E-mail: riprent@open.telekom.rs.

5 Dr Branislav Živković, Tehnička škola Žagubica, Homoljska bb, 12320 Žagubica, Srbija, E-mail:mrbane71@gmail.com

6 Redovni profesor, dr Drago Cvijanović, naučni savetnik i dekan, Fakulteta za hotelijerstvo i turizam u Vrnjačkoj Banji, Univerziteta u Kragujevcu, Vojvođanska 5A, 36210 Vrnjačka Banja, Srbija, Teefon: + 38163295 111, E-mail: drago.cvijanovic@kg.ac.rs i dvcmmv@gmail.com

EP 2016 (63) 1 (71-87) 